\title{
'Mountain Majesty': A Tomato Spotted Wilt Virus-resistant Fresh-market Hybrid Tomato and Its Parents NC 714 and NC 1CS
}

\author{
Dilip R. Panthee ${ }^{1}$ and Randy G. Gardner \\ Department of Horticultural Science, North Carolina State University, \\ Mountain Horticultural Crops Research and Extension Center (MHCREC), \\ 455 Research Drive, Mills River, NC 28759-3423
}

Additional index words. crimson, graywall resistant, large-fruited, $\mathrm{og}^{\mathrm{c}}$ gene, $S w-5$ gene

\begin{abstract}
'Mountain Majesty' is a large-fruited, freshmarket hybrid tomato (Solanum lycopersicum L.) developed by crossing NC $714 \times$ NC 1 CS. It is resistant to verticillium wilt (Verticillium dahliae Kleb) (race 1), fusarium wilt [Fusarium oxysporum f.sp. lycopersici (Sacc.) Snyd. and Hans.] (races 1 and 2), and tomato spotted wilt virus (TSWV).
\end{abstract}

\section{Origin}

'Mountain Majesty', the $\mathrm{F}_{1}$ hybrid of NC $714 \times$ NC 1CS (Fig. 1), resulted from a tomato breeding effort to develop a superior largefruited hybrid tomato with improved fruit color based on the crimson $\left(\operatorname{og}^{c}\right)$ gene combined with fusarium wilt, verticillium wilt, and TSWV resistances adapted to vine-ripe production in North Carolina (NC).

NC 714 resulted from selfing $\mathrm{NC} 03113$, the $\mathrm{F}_{1}$ hybrid of Fla $8044 \times \mathrm{NC}$ 00318-15(x)-1 (Fig. 1). Fla 8044 is a large-fruited, hightemperature fruit set line with desirable horticultural traits and multiple disease resistance genes obtained from the University of Florida tomato breeding program. NC 00318-15(x)-1 is an $\mathrm{F}_{2}$ selection obtained by crossing a male sterile version of NC 84173 with an $\mathrm{F}_{3}$ generation line derived from selfing the North Carolina State University (NCSU)-released hybrid 'Mountain Crest' (NC $84173 \times$ NC 1 rinEC) (Gardner, 2006). The crimson gene in $\mathrm{NC} 714$ was derived from the NC 1rinEC parent of 'Mountain Crest' and Fla 8044. The objective of breeding NC 714 was to incorporate desirable fruit characteristics and superior combining ability from NC 84173 (Gardner, 1992) together with the crimson gene for increased red fruit color and lycopene content. Single plant selections were made for large fruit size, high yield, and other desirable horticultural

\footnotetext{
Received for publication 2 May 2011. Accepted for publication 13 July 2011.

The tomato breeding program of North Carolina State University was supported by the North Carolina Tomato Growers Association and the Hatch project of USDA.

${ }^{1}$ To whom reprint requests should be addressed; e-mail Dilip_panthee@ncsu.edu.
}

traits in the $F_{2}$ through $F_{5}$ generations derived from selfing $\mathrm{NC} 03113$.

NC 1 CS resulted from selfing $\mathrm{NC} 056$, the $\mathrm{F}_{1}$ hybrid of NC $123 \mathrm{~S} \times \mathrm{NC} 0255(\mathrm{x})-1$ (Fig. 1). NC $123 \mathrm{~S}$, which combines single dominant gene resistances to TSWV, fusarium wilt race 3 , and nematodes ( $\mathrm{Sw}-5, \mathrm{I}-3, \mathrm{Mi}$ genes) and was released from the $\mathrm{NC}$ breeding program. 'Amelia' $F_{1}$ hybrid, from which NC $123 \mathrm{~S}$ was developed, is a codeveloped hybrid using NC $111 \mathrm{~F}-2(98)$ as a source of the $I-3$ gene for fusarium wilt race 3 resistance crossed with a Clause Seed Company proprietary line having the $S w-5$ and $M i$ genes. NC $0255(\mathrm{x})-1$ is an outstanding large-fruited selection with the crimson gene that traces its pedigree back to breeding lines and cultivars developed in the NC tomato breeding program over a 25year period (Fig. 1). The source of the crimson gene in NC 0255(x)-1 is 'Suncoast', an inbred cultivar released from the University of Florida breeding program.

\section{Description}

'Mountain Majesty' has a vigorous determinate growth habit ( $s p$ gene) similar in height to that of 'Mountain Fresh'. Foliage provides good cover for fruit protection. 'Mountain Majesty' has homozygous resistance (Ve gene) to Verticillium dahliae Kleb., resistance (I, I-2 genes) to races 1 and 2 of Fusarium oxysporum f.sp. lycopersici (Sacc.) Snyd. and Hans., and heterozygous resistance to TSWV ( $\mathrm{Sw}-5$ gene). Total and marketable yields of 'Mountain Majesty' were significantly higher than 'Mountain Fresh' in 2008 when there was TSWV infection in the field (Table 1). Fruit of 'Mountain Majesty' have been free of graywall in grower plantings where fruit of 'Mountain Fresh' exhibited some graywall symptoms. Graywall is a disorder in tomato fruits in which affected green fruits have large patches of hard, grayish or yellowish tissue. This causes poorly or uneven ripening of fruits.

Fruit of 'Mountain Majesty' develop a deep red color resulting from the crimson gene and are firm in the fully ripened stage. Immature fruits have a glossy, uniform green color ( $u$ gene). Fruit pedicels are jointed, and the fruit separate easily from the pedicels during harvest. The fruit are deep oblate to flattened globe in shape with generally smooth blossom end scars and have good resistance to fruit cracking and weather check. Weather check is a condition in tomato fruits in which small cracks in the cuticle may enlarge considerably if there is presence of water (mist, fog, dew) for extended periods of time. This may be conducive for fungi or bacteria to invade the fruits. 'Mountain Majesty' has performed well in numerous observational trials in research station and grower fields throughout the mountains and piedmont of $\mathrm{NC}$, and in coastal area of South Carolina. Flavor of 'Mountain Majesty' has been rated good in subjective test evaluation in research station plots and by growers and consumers of fruit produced and marketed from grower trial plantings.

When averaged over six replicated trials conducted at Mountain Horticultural Crops Research and Extension Center in early and late plantings in the summer seasons of 2008 to 2010 with production system of black plastic mulch, fumigated with methyl bromide, staked, and strung, 'Mountain Majesty' was equivalent to 'Mountain Fresh' (Gardner, 1999) in total yield, U.S. combination grade yield, percent combination grade fruit, and fruit size (Table 2). A high percentage of the fruit of 'Mountain Majesty' were in the jumbo size category (greater than 3.5-inch diameter), which is highly desirable for vine-ripe tomatoes and for which growers are often paid a premium over smaller fruit sizes. 'Mountain Majesty' exceeded the TSWV-resistant hybrids 'Mountain Glory' and 'Fletcher' in total yield, combination grade yield, and fruit size when averaged over the six replicated trials (Table 2).

Plant growth habit of NC 714 is vigorous, determinate with attractive, heavy foliage cover. Fruit are very large, smooth, deep globe (ball) in shape, similar to NC 84173, and have jointed pedicels. Immature fruit are uniformly light green ( $u$ gene). Ripe fruit are firm and develop a bright red exterior and interior color as a result of the crimson gene. Disease resistances include verticillium wilt ( $V e$ gene) and races 1 and 2 of fusarium wilt ( $I$ and $I-2$ genes).

In replicated vine-ripe harvest and mature-green harvest trials in 2008 to 2010 , NC 714 produced high total yields compared with standard check hybrids and had large fruit size (Table 2). Graded yield of NC 714 was reduced by the occurrence of weather check, which is a problem in $\mathrm{NC} 714$, NC 84173 , and other lines of tomatoes with the large deep globe (ball shape) trait. The large ball shape is useful in developing very largefruited lines, which combine well for improved fruit size in $F_{1}$ hybrids. Because the ball shape trait is recessive when crossed to normal flattened globe to oblate tomatoes, the susceptibility to weather check is not present in $\mathrm{F}_{1}$ hybrids made with this fruit type as a parent. Several NCSU-released hybrids and seed company hybrids make use of a large ballshaped tomato as one of the parent lines in hybrids.

Average fruit weight of NC 714 of $\approx 310 \mathrm{~g}$ over the replicated trials grown was significantly 


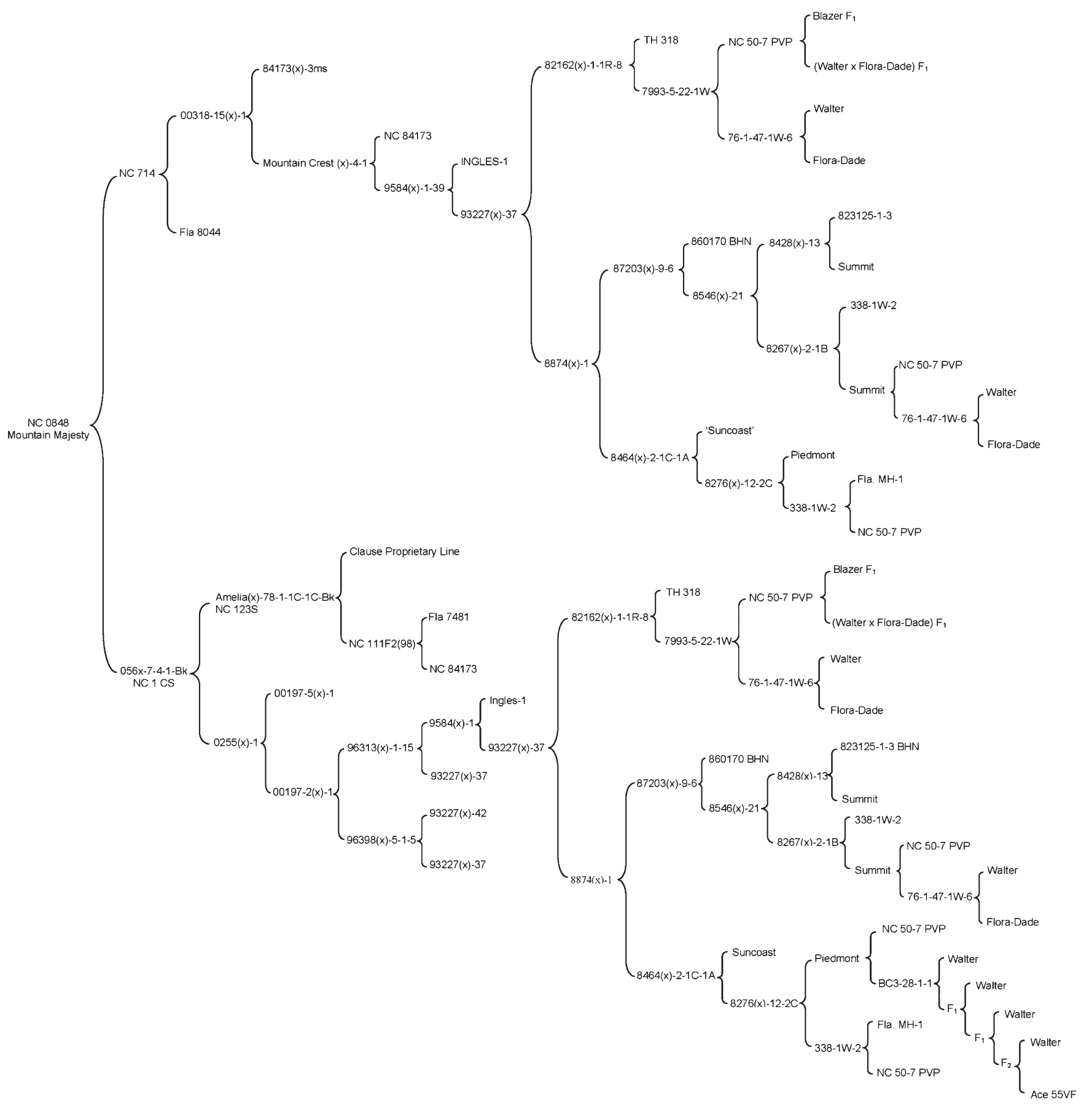

Fig. 1. Pedigree of 'Mountain Majesty' hybrid tomato.

Table 1. Average performance of 'Mountain Majesty' and its parents, NC 714 and NC 1CS, compared with standard hybrids in 2008 at Mills River, NC, where tomato spotted wilt virus was present.

\begin{tabular}{lcccr}
\hline Cultivar & $\begin{array}{c}\text { Non-graded } \\
\text { yield }\left(\mathrm{t} \cdot \mathrm{ha}^{-1}\right)\end{array}$ & $\begin{array}{c}\text { Graded } \\
\text { yield }\left(\mathrm{t} \cdot \mathrm{ha}^{-1}\right)\end{array}$ & $\begin{array}{c}\text { Marketable } \\
(\%)\end{array}$ & $\begin{array}{c}\text { Fruit } \\
\mathrm{wt}(\mathrm{g})\end{array}$ \\
\hline Fletcher & 100 & 60 & 61 & 285 \\
Mountain Fresh & 102 & 62 & 60 & 320 \\
Mountain Glory & 99 & 68 & 69 & 283 \\
Mountain Majesty & 130 & 86 & 66 & 321 \\
NC 1CS & 123 & 77 & 62 & 318 \\
NC714 & 121 & 50 & 42 & 337 \\
Least significant difference $(0.05)$ & 12 & 10 & 8 & 20 \\
\hline
\end{tabular}

higher than most of the other entries in trial (Table 2). Considering its superior yield, large fruit size, and good combining ability, it is being used as a parent in additional crosses. NC 714 is not intended for use as a cultivar but solely as a parent for its contribution of large fruit size, the crimson gene, and other desirable horticultural traits and disease resistance genes when used as a parent in $\mathrm{F}_{1}$ hybrids. $\mathrm{NC} 714$ is the first line developed for release from the NCSU tomato breeding program that combines the crimson gene with the large ball-shaped trait. It is intended for crossing with other lines having the recessive crimson gene so the hybrids will be homozygous for crimson and express improved red color and increased lycopene content.

Plant growth habit of NC 1CS is vigorous, determinate with attractive, heavy foliage cover. Fruit are deep oblate to flattened globe in shape, are smooth, and have jointed pedicels. Immature fruit are uniform light green ( $u$ gene). Ripe fruit are firm and develop exceptionally bright red exterior and interior color as a result of the crimson gene. NC 1CS is resistant to 
Table 2. Average performance of 'Mountain Majesty' and its parents, NC 714 and NC 1CS, compared with control hybrid tomatoes grown in field trials at Mills River, NC (2008 to 2010).

\begin{tabular}{|c|c|c|c|c|}
\hline Cultivar & $\begin{array}{l}\text { Non-graded } \\
\text { yield }\left(\mathrm{t} \cdot \mathrm{ha}^{-1}\right)\end{array}$ & $\begin{array}{c}\text { Graded } \\
\text { yield }\left(\mathrm{t} \cdot \mathrm{ha}^{-1}\right)\end{array}$ & $\begin{array}{c}\text { Marketable } \\
(\%)\end{array}$ & $\begin{array}{l}\text { Fruit } \\
\text { wt (g) }\end{array}$ \\
\hline Fletcher & 86 & 51 & 59 & 277 \\
\hline Mountain Fresh & 99 & 62 & 62 & 314 \\
\hline Mountain Glory & 87 & 60 & 69 & 281 \\
\hline Mountain Majesty & 106 & 70 & 67 & 321 \\
\hline $\mathrm{NC} 1 \mathrm{CS}$ & 110 & 77 & 71 & 325 \\
\hline $\mathrm{NC714}$ & 115 & 54 & 48 & 310 \\
\hline Least significant difference $_{(0.05)}$ & 11 & 9 & 6 & 22 \\
\hline
\end{tabular}

verticillum wilt ( $V e$ gene), races 1 and 2 of fusarium wilt (I, I-2 genes), and TSWV ( $\mathrm{Sw}-5$ gene). Details of these genes can be found at http://tgrc.ucdavis.edu/Data/Acc/Genes.aspx. Fruit are highly resistant to graywall and cracking. In 2007, in replicated vine-ripe and mature-green harvest trials where TSWV was severe, NC 1Cs produced higher total and marketable grade yields than susceptible cultivars and was free of TSWV. In replicated vineripe harvest trials in 2008, where TSWV was present, NC 1 CS produced high total and U.S. combination grade yields compared with other entries and had large fruit size (Table 1). NC 1 CS continued to perform well in early- and late-season vine-ripe harvest trials in 2008 to 2010 (Table 2) and has exhibited good combining ability in numerous experimental hy-

'Mountain Majesty' provides growers in North Carolina and other regions with similar growing conditions a high-yielding, TSWVresistant, fresh-market, large-fruited tomato cultivar with improved color and fruit size comparable to 'Mountain Fresh'. The addition of resistance to TSWV, large fruit size, fruit smoothness, and high yielding potential are extremely useful to tomato growers in $\mathrm{NC}$ and other states. NC 714 and NC 1CS provide tomato breeders with superior fruit quality and yield potential and should be useful in breeding as a parent in other $\mathrm{F}_{1}$ hybrids.

\section{Availability}

We plan to license 'Mountain Majesty' to a private seed company on an exclusive basis for seed production and sales. It is expected that commercial seed should be available in 2013. Distribution of seed of NC 714 and NC $1 \mathrm{CS}$ to other breeders requires a signed material transfer agreement, which can be downloaded at the following web site address: <http://www.mountainhort.ncsu.edu/ programs/tomato/releases/tomato-seed-transferagreement.pdf $>$. Small trial samples of 'Mountain Majesty' are available from D.R. Panthee (dilip_panthee@ncsu.edu), MHCREC, 455 Research Drive, Mills River, NC 28759.

\section{Literature Cited}

Gardner, R.G. 1992. 'Mountain Spring' tomatoNC-8276 and NC-84173 tomato breeding lines. HortScience 27:1233-1234.

Gardner, R.G. 1999. NC 109 tomato breeding line: 'Mountain Fresh' $F_{1}$ hybrid. HortScience 34: 941-942.

Gardner, R.G. 2006. 'Mountain Crest' hybrid tomato and its parent, NC 1 rinEC. HortScience $41: 261-262$. 